\title{
Design and validation of a questionnaire to study healthy habits among adolescents aged 12-14 years
}

\author{
M. Isabel Jiménez Candel, B.S. ${ }^{a}$, Pedro J. Carpena Lucas, B.S. ${ }^{a}$, \\ Guillermo Ceballos-Santamaría, M.D. ${ }^{b}$ and José Mondéjar Jiménez, Professor ${ }^{b}$
}

\begin{abstract}
Introduction. Social and cultural changes are altering young people's habits. Some surveys measure such behaviors, but are hard to interpret. The objective of this study was to design and validate a homogeneous questionnaire to study habits among adolescents aged 12-14 years.

Population and methods. Descriptive and crosssectional study to validate a questionnaire. Items were selected after a bibliographic review and expert assessment. The pre-test was administered to a pilot sample. Reliability was established using Cronbach's alpha coefficient, and construct validity, using a factor analysis. It was administered to a sample of parents of students from 4 secondary schools.

Results. Cronbach's coefficient showed values close to 0.7 in $3 / 4$ subscales and an overall value of 0.629 , showing accuracy and stability. Factor analysis determined an adequate construct validity, with 4 factors: eating, physical activity, new technologies, and environment. The final questionnaire included 26 items and was administered to 421 participants. Poor habits were observed in $24.8 \%$ and very unhealthy, in $3.4 \%$. Girls had poorer scores in physical activity $(p<0.001)$, and boys, in new technologies, although it was not significant.

Conclusions. The final instrument was valid, reliable, and easily administered to assess modifiable behaviors in adolescents. The inclusion of technologies and environment helps to adapt the questionnaire to current changes. The greatest deficit was observed in the technology use and physical activity domains; and girls were more sedentary.
\end{abstract}

Key words: surveys and questionnaires, lifestyles, adolescent, primary prevention, obesity.

http: / / dx.doi.org/10.5546/ aap.2021.eng.177

To cite: Jiménez Candel MI, Carpena Lucas PJ, Ceballos-Santamaría G, Mondéjar Jiménez J. Design and validation of a questionnaire to study healthy habits among adolescents aged 12-14 years. Arch Argent Pediatr 2021;119(3):177-184.

\section{INTRODUCTION}

Recent social and cultural changes are modifying adolescents' behaviors and habits. A diet based on fast foods, doing little physical activity and the technological revolution, which leads to a more sedentary lifestyle, are now a reality. ${ }^{1-3}$ These patterns are contributing to the rapid increase in pediatric overweight and obesity in recent decades. ${ }^{3-8}$ In terms of pediatric overweight and obesity, Spain is the leader in Europe with 20-24\% and $10-15 \%$, respectively. ${ }^{9-11}$ Obesity is a multifactorial problem in which genetic, metabolic, psychosocial, and environmental determinants are involved. The latter are becoming increasingly important as they are modifiable. ${ }^{12}$

The period with the most opportunities to acquire healthy behaviors that will last for life is puberty ${ }^{13}$ because this is when physiological, psychological, and behavioral changes that are critical for human development occur. Detecting, preventing, and improving lifestyle habits is a challenge for public health. ${ }^{10,14}$ Hence, the importance of establishing how environmental factors have an impact on adolescents' health so that cases at risk are detected in an early manner. Screening tests should be administered to detect children with unhealthy habits.

According to the bibliography, multiple surveys have been developed in an attempt to establish children's habits and behaviors. Specific questionnaires have been developed about eating habits, such as the National Survey on Food and Beverage Consumption in the Child and Adolescent Population; ${ }^{15}$ 
physical activity, such as the Assessment of Physical Activity Levels Questionnaire (APALQ) ${ }^{16}$ or the ENERGY; ${ }^{17}$ in addition to scales about Experiences related to video games, the Internet or mobile phones (CERV, CERI, and CERM), respectively. ${ }^{18}$ Other studies, such as the Surveillance on Growth, Diet, Physical Activity, Child Development, and Obesity (Vigilancia Del Crecimiento, ALimentación, Actividad Física, Desarrollo Infantil y Obesidad, ALADINO), ${ }^{10}$ have analyzed the overall domain of health using surveys. All of these instruments have provided great knowledge about young people's habits, but had a limitation: using different measurement scales and data collection methods has hurdled administration, interpretation, and population comparison possibilities.

Thus, it is necessary to develop an instrument capable of analyzing each risk factor affecting excess weight from an overall perspective; a homogeneous, brief, easily administered scale that allows analyzing results, their relation, and data extrapolation. A practical, useful questionnaire may serve as a screening tool in both the school and primary care settings. Therefore, the main objective of this study was to design and validate a questionnaire to study health-related habits and behaviors among children aged 12-14 years.

\section{POPULATION AND METHOD}

This was an observational and cross-sectional validation study divided into the following phases: questionnaire development, validation, and administration.

\section{Questionnaire design}

An extensive bibliographic review was done using the PubMed, MEDLINE, Cochrane Library, SCOPUS, Google Scholar, and Web of Science electronic databases. Search terms included eating habits, physical exercise, child health, information and communication technologies, video games, school, school performance, leisure time, personal relations, self-perception, social acceptance, happiness, satisfaction, and child obesity. Based on this, a preliminary questionnaire was developed and reviewed by five experts in pediatrics and adolescent medicine for content validation.

An odd Likert scale made up of 11 items was used, where a score close to 0 accounted for unhealthier habits; the questionnaire was homogeneous, comparable, and simple. The scoring method was the sum of each item (total range: $0-260)$. Some were arranged contrary to the construct, so they were inverted for analysis. Cutoff points were established to determine groups by score: 0-49, very unhealthy habits; 50-99, unhealthy; 100-149, acceptable; 150-200, healthy; and $>200$, very healthy.

The pre-test was administered to a pilot sample of 37 parents from a different school. Doubts, incidences, and remarks were registered. After the reliability analysis, non-discriminatory questions (those correctly answered by more than $95 \%$ of the sample) or questions with low internal reliability were removed. The estimated time to complete the questionnaire was 10 minutes.

\section{Psychometric analysis}

Using Cronbach's alpha, the more reliable items were determined. An internal consistency between 0.4 and 0.7 was accepted, ${ }^{19}$ and this version was made up of 27 items. Then, an exploratory factor analysis using the maximum likelihood method and varimax rotation factors was done to identify the questionnaire's underlying structure and determine construct validity. Relevance was previously studied using the Kaiser-Meyer-Olkin (KMO) measure of sampling adequacy and Bartlett's sphericity test. KMO values above 0.7 were accepted to assess the extent of correlation among variables.

After this, the total variance explained was done selecting values above $50 \%$. Minimum values of 0.3 were admitted as optimal for item correlation with the corresponding factor for grouping. Initially, 8 rotations were obtained, which were subjected to a retention for convenience to unify and reduce domains, and an optimized, 4-component version was obtained. The final questionnaire included 26 items distributed in 4 domains. Finally, the scores were examined to look for differences based on sex using a variance analysis.

\section{Field test}

The target population was made up of parents of adolescents who were in the first year of secondary school (12-14 years) in education centers from health area $\mathrm{V}$ of the Region of Murcia during the 2017-2019 period. Taking into account the population in that age range included in the census, a minimum sample size of 350 participants was calculated for a maximum error of $4.92 \%$, with a $95 \%$ confidence interval. The seven education centers in the area were invited to participate in the study; four (three public and one state-funded private) 
agreed to collaborate; three public schools refused to participate alleging lack of time in the school schedule. Participants were selected from an eligible sample of 567 students, and the proportion among centers was maintained.

The questionnaire was sent to the parents for its completion at home, together with the informed consent and an explanatory note that included information about the study, its objectives, voluntary nature, and anonymity of answers. Parents whose adolescent children had chronic diseases or eating disorders and those who refused to participate were excluded.

All data were anonymous and results were analyzed using the Statistical Package for the Social Sciences (SPSS). The study was accepted by the Clinical Research Ethics Committee of Hospital Universitario Virgen de la Arrixaca (Murcia).

\section{RESULTS}

1. Questionnaire development

A total of 636 articles in Spanish and English were identified; of these, 15 related to large national studies and validated surveys in the child population were selected. Based on the most prevalent and representative items, a 51-item questionnaire was obtained; this was assessed by experts, who removed 5 items due to a lack of construct or controversy. A pilot questionnaire of 46 items distributed into 4 sections was developed: eating included 14 items, physical activity-leisure time, 5; new technologies, 10; and school-friends, 17. Figure 1 shows the questionnaire development process. This pre-test was correctly completed by $95 \%$ of the pilot sample, and an adequate feasibility was confirmed.

\section{Psychometric analysis}

In relation to the validity and reliability study, after a Cronbach's alpha analysis, the eating block was reduced to 8 items, and the questions about water, salt, or pastry were removed, among others. In relation to physical activity-leisure time, the 5 items were maintained. For new technologies, 3 questions about parental supervision, use of

FIGURE 1. Baseline characteristics and Cronbach's alpha progress

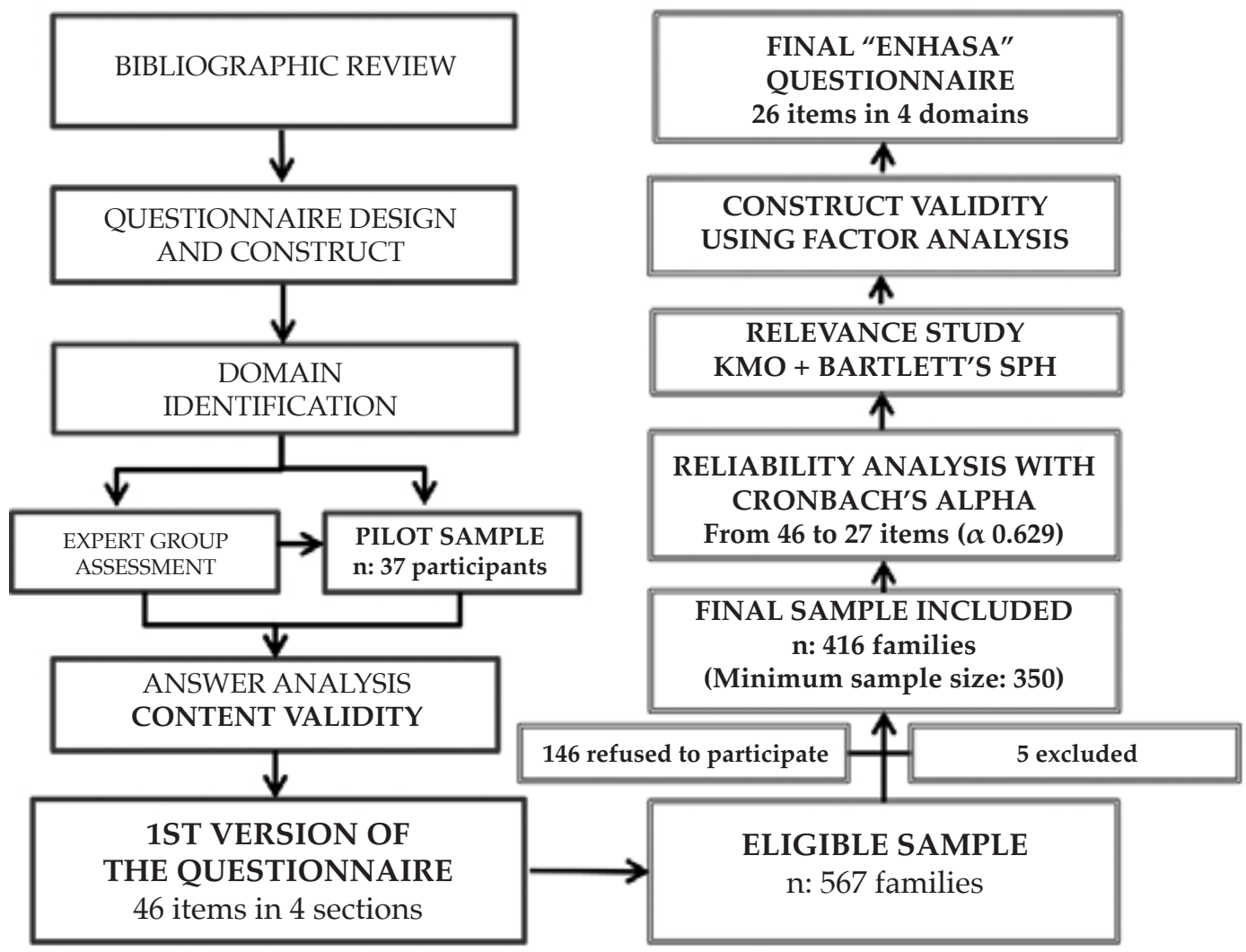

ENHASA: Survey on healthy habits among adolescents (Encuesta de Hábitos Saludables en Adolescentes);

KMO: Kaiser-Meyer-Olkin measure of sampling adequacy. 
parental controls, and electronic material use in the classroom were removed. Finally, the schoolfriends block was reduced to 7 questions with the elimination of those about academic performance, peer relations, and mood. Table 1 shows how the alpha coefficient increased as low discrimination items were removed.
The final set showed an overall internal consistency of 0.629 . The sample adequacy study showed a KMO value of 0.752 , and Bartlett's test, a $p$ value $<0.05$. After the exploratory analysis, 8 components had an eigenvalue $\geq 1$. This solution accounted for a significant total variance percentage $(58.8 \%)$. After the retention

TABLE 1. Baseline characteristics and Cronbach's alpha progress

\begin{tabular}{llccccc}
\hline & & Eating & Physical activity & New technologies & Environment & Overall \\
\hline Initial test & No. of items & 14 & 5 & 10 & 17 & 46 \\
\multirow{2}{*}{ Resulting test } & Alpha value & 0.456 & 0.500 & 0.590 & 0.468 & 0.585 \\
& No. of items & 8 & 5 & 7 & 7 & $\mathbf{2 7}$ \\
& Alpha value & 0.665 & 0.500 & 0.759 & 0.758 & $\mathbf{0 . 6 2 9}$ \\
\hline
\end{tabular}

Reliability analysis results. After removing the less reliable items from the initial test, an abridged version with a higher internal consistency both per domain and overall was obtained.

TABLE 2. Rotation matrix for 4 components

\begin{tabular}{lcc}
\hline & \multicolumn{1}{c}{ Component } \\
\cline { 2 - 2 } Eating & $\mathbf{1}$ & $\mathbf{3}$ \\
& & 4 \\
2. Brings lunch from home. & 0.535 \\
3. Has at least four meals a day. & 0.4 \\
4. Eats fruits every day. & 0.747 \\
5. Eats vegetables every day. & 0.726 \\
6. Eats fish several times a week. & 0.687 \\
7. Eats legumes several times a week. & 0.706 \\
8. Eats processed or fast food (pizza, hamburgers...) several times a week. & 0.39 \\
13. Eats together with the family. & 0.371 \\
\hline Physical activity & \\
15. Walks to school. & 0.754 \\
16. Does aerobic physical activity (running, riding a bike) every day, for at least 60 minutes. & 0.693 \\
17. Does a sport-related extracurricular activity, e.g., skating, basketball, dancing, etc. & 0.508 \\
18. Does physical activity with their family, e.g., walking, riding a bike, hiking, etc. & 0.343 \\
19. Has had enough time for leisure activities: playing, reading, etc. & 0.319 \\
\hline
\end{tabular}

New technologies

$\begin{array}{lc}\text { 20. Watches TV. } & 0.439 \\ \text { 21. Uses a computer, mobile phone or tablet to play video games. } & 0.62 \\ \text { 22. Uses a computer, mobile phone or tablet to go online. } & 0.768 \\ \text { 23. Uses a computer, mobile phone or tablet to chat with friends. } & 0.762 \\ \text { 24. Has a total screen time of } 2 \text { or more hours a day } & \end{array}$

(computer, tablet, mobile phone... combined). 0.671

28. Your child gets angry if somebody bothers them while using their mobile phone. $\quad 0.553$

29. You have told someone that your child spends too much time using the phone

or watching TV.

\section{Environment}

36. Has been bullied or threatened by other children.

37. Is scared of other children.

38. Is ashamed of themselves or would like to change a part of their body. $\quad 0.618$

39. Has felt everything goes wrong.

0.749

40. Has felt lonely.

41. Has complained that their parents do not have enough time for them.

42. Has complained that they are treated unfairly at home. 
for convenience, a final, optimized version made up of 4 domains was obtained: technologies, environment, eating, and physical activity-leisure time. Item distribution and factor load are shown in Table 2.

TABLE 3. Demographic characteristics of participants

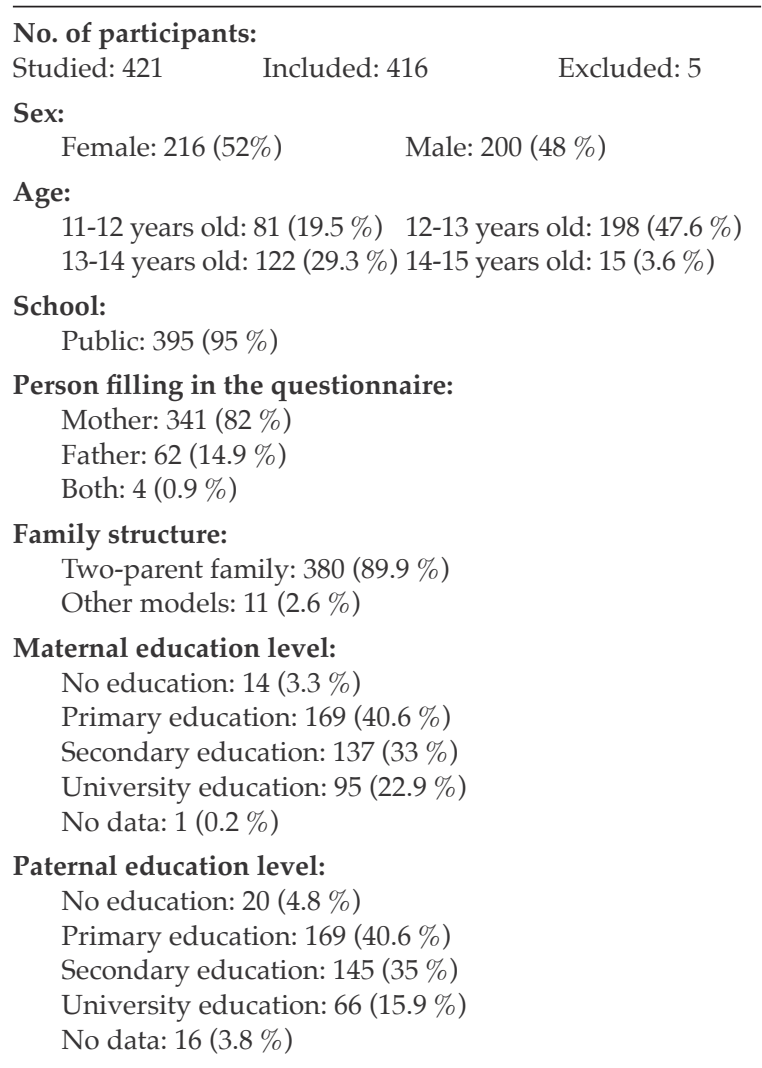

The item related to fast food consumption showed a greater load in the new technologies factor, as well as the eating together as a family item in the physical activity domain, but both were moved to the eating domain because they had no conceptual relevance in the other domains. The walks to school item showed similar loads in the 4 factors, but they were all below 0.3 , so it was not assigned to any of them. The final questionnaire, called Survey on healthy habits among adolescents (Encuesta de Hábitos Saludables en Adolescentes, ENHASA), maintained the same 4 domains and included 26 items.

\section{Analysis of results}

A total of 421 "parent-student" pairs were recruited (participation rate: $74.2 \%$ ). Students' mean age was $12.8 \pm 0.6$ years and standard deviations (SDs); $52 \%$ of participants were girls. Five participants were excluded because they had a chronic disease. Table 3 shows a breakdown of the sample's demographic characteristics.

Based on the score, $28.2 \%$ of participants had poor habits; of them, $3.4 \%$ were very unhealthy. Only $9.1 \%$ of participants had very healthy habits. The analysis of variance did not find significant general differences by sex ( $p$ 0.417).

The greatest deficit was observed in the technology use domain, followed by physical activity $(40.8 \%$ and $47.4 \%$ of the maximum potential score). Eating habits were adequate in general, with mean scores of $74.9 \%$ of the potential score. Table 4 shows a summary of regulatory data for scores in general and per

TABLE 4. Definite and descriptive questionnaire data by sex

\begin{tabular}{|c|c|c|c|c|c|}
\hline Domain & No. of items & & Girls $(n=216)$ & Boys $(n=200)$ & $p$ value \\
\hline Eating & 8 & $\begin{array}{l}\text { Mean } \\
\text { Standard deviation } \\
\text { Range }\end{array}$ & $\begin{array}{c}57.93 \\
11.819 \\
17-80\end{array}$ & $\begin{array}{c}58.01 \\
11.315 \\
20-79\end{array}$ & 0.944 \\
\hline Physical activity & 4 & $\begin{array}{l}\text { Mean } \\
\text { Standard deviation } \\
\text { Range }\end{array}$ & $\begin{array}{c}17.62 \\
8.674 \\
0-40\end{array}$ & $\begin{array}{c}20.41 \\
7.368 \\
0-35\end{array}$ & 0.000 \\
\hline New technologies & 7 & $\begin{array}{l}\text { Mean } \\
\text { Standard deviation } \\
\text { Range }\end{array}$ & $\begin{array}{c}29.35 \\
15.168 \\
0-63\end{array}$ & $\begin{array}{c}22.75 \\
13.906 \\
0-65\end{array}$ & 0.265 \\
\hline Environment & 7 & $\begin{array}{l}\text { Mean } \\
\text { Standard deviation } \\
\text { Range }\end{array}$ & $\begin{array}{c}58.27 \\
12.013 \\
17-70\end{array}$ & $\begin{array}{c}59.11 \\
11.248 \\
15-70\end{array}$ & 0.468 \\
\hline Total & 26 & $\begin{array}{l}\text { Mean } \\
\text { Standard deviation } \\
\text { Range }\end{array}$ & $\begin{array}{c}163.171 \\
31.87 \\
66-229\end{array}$ & $\begin{array}{c}165.27 \\
27.24 \\
73-237\end{array}$ & 0.471 \\
\hline
\end{tabular}

Final score, by block and overall, based on sex. n: 416 . 
domain based on sex. Girls had poorer scores in physical activity $(p<0.001)$, and boys, in new technologies, although it was not significant.

\section{DISCUSSION}

The instrument obtained contains acceptable psychometric parameters and is simple and quick. The ENHASA showed an acceptable internal consistency, making it an accurate and stable tool to assess lifestyle habits among adolescents. It is an improvement from previous instruments because, in addition to including multiple areas affecting health, it uses a homogeneous answer scale and provides measurable data that are easily coded and interpreted.

Using a factor analysis, all aspects were grouped into 4 domains and items that provide related summary information were developed, which allows to establish customized and individualized improvement strategies based on the deficit area. It also validates the questionnaire structure, consistent with the existing bibliography. ${ }^{10,20-24}$

The ENHASA includes the habits most related to obesity, such as eating and physical activity, and it also introduces aspects like environment and new technologies, which are essential for an overall approach to child health. ${ }^{12}$ The eating domain includes legume, fish, fruits, and vegetables consumption, which has been related to a higher body mass index and metabolic syndrome. ${ }^{21}$ Consumption of these food groups should be encouraged, whereas precooked foods, sodas, and sweets should be reduced. ${ }^{25}$

In relation to physical activity, a higher factor load was observed in questions related to the recommendations by the World Health Organization (WHO) ${ }^{26}$ and extracurricular sport-related activities. Physical exercise during childhood has an impact on growth and reduces morbidity and mortality in adult age. ${ }^{25-27}$ Although walking to school has been promoted as a prevention strategy, ${ }^{10}$ in our study, the load was not sufficient, probably because the study population comes from a rural setting, where most students walk to school.

In relation to the technologies domain, the digital revolution has led to an important increase in screen use, at the expense of physical and leisure activities. Both the Spanish Society of Pediatrics and the American Academy of Pediatrics recommend limiting screen time to less than 2 hours a day due to its association with obesity. ${ }^{8,28,29}$ Given the dose-response relationship between screen time and excess weight, ${ }^{14,21}$ more attention should be given to new technologies as factors that affect health.

Finally, in the environment domain, the higher load was observed in items related to self-esteem and bullying. Sensitive or conflictive situations are often left out of child assessments, but it is necessary to consider that, during childhood and adolescence, changes that will have an effect on health and well-being in adult life take place. ${ }^{13,30}$ This is in addition to the poorer self-esteem and quality of life observed among obese children. ${ }^{31}$

In our sample, 1 in 4 adolescents referred unhealthy habits, which showed an unbalanced diet, a sedentary lifestyle, and an excessive use of technology. The worst habits were observed in the technology use and physical activity domains. More sedentary behaviors were observed among girls, which is consistent with national studies. ${ }^{20}$ Unlike the bibliography, eating habits were adequate, probably because rural area populations like the one in our study tend to follow the Mediterranean diet. ${ }^{32}$ The greatest deficit area in both males and females was new technologies. Nowadays, many learning, communication, and entertainment hours take place in front of a screen, which is why the obtained results are consistent.

Instruments to measure attitudes and behaviors are required in pediatrics so as to prevent associated comorbidities. Using this type of instruments helps to obtain a better quality in terms of data collection, which is good to detect risks for child health and establish an early management. The design by domains allows to appropriately plan health care, including targeted prevention strategies based on the deficit area. As health programs now include other support tools to detect hypothyroidism or hearing loss in children, this type of validated instruments should be included in the assessment of risk habits.

The main limitations of this study were the lack of correlation with other scales, given that we did not find any other similar instrument that had been validated in the pediatric population, and that this was an observational study, so it was not possible to establish causality among studied factors.

To conclude, the ENHASA is a valid, reliable, and easily administered instrument to assess the main modifiable behaviors among adolescents. The inclusion of new technologies and environment as influential factors helps to 
adapt the questionnaire to current social changes. The greatest deficit was observed in habits related to new technologies and physical activity; and girls were more sedentary. The ENHASA is an optimal instrument to detect children at risk and to establish customized prevention and treatment strategies.

\section{REFERENCES}

1. Coronel Rodríguez C, González Zorzano E, Hernández Hernández A, Escolar Jurado M, et al. Encuesta epidemiológica sobre la percepción y hábitos de salud de las familias españolas sobre nutrición infantil. Pediatr Integr. 2017; 21(3):221.e1-12.

2. García-Continente $X$, Allué N, Pérez-Giménez A, Ariza $\mathrm{C}$, et al. Hábitos alimentarios, conductas sedentarias y sobrepeso y obesidad en adolescentes de Barcelona. An Pediatr (Barc). 2015; 83(1):3-10.

3. World Health Organization. The World Health Report 2002. Reducing risks, promoting healthy life. Geneva;WHO; 2002. [Accessed on: November 12 ${ }^{\text {th }}, 2020$ ]. Available at: https: / / apps.who.int/iris / bitstream / handle / 10665 / 42510 / WHR_2002.pdf;jsessionid=F96A47F5B1396712B3EBE732 B2BACCB3? sequence $=1$.

4. Lobstein T, Jackson-Leach R, Moodie ML, Hall KD, et al. Child and adolescent obesity: Part of a bigger picture. Lancet. 2015; 385(9986):2510-20.

5. Blanco M, Veiga OL, Sepúlveda AR, Izquierdo-Gómez R, et al. Ambiente familiar, actividad física y sedentarismo en preadolescentes con obesidad infantil: estudio ANOBAS de casos-controles. Aten Primaria. 2020; 52(4):250-7.

6. Zurriaga O, Pérez-Panadés J, Quiles Izquierdo J, Gil Costa $\mathrm{M}$, et al. Factors associated with childhood obesity in Spain. the OBICE study: A case-control study based on sentinel networks. Public Health Nutr. 2011; 14(6):1105-13.

7. Ninatanta-OrtizaJA, Núñez-Zambranoa LA, García-Flores SA, Romaní Romaní F. Factores asociados a sobrepeso y obesidad en estudiantes de educación secundaria. Rev Pediatr Aten Primaria. 2017; 19(75):209-21.

8. Lajunen HR, Keski-Rahkonen A, Pulkkinen L, Rose RJ, et al. Are computer and cell phone use associated with body mass index and overweight? A population study among twin adolescents. BMC Public Health. 2007; 7:24.

9. World Health Organization. Glabal prevalence and secular trends in obesity. In: Obesity: preventing and managing the global epidemic. Geneva: WHO; 2000.Pages 16-60. [Accessed on: November 15 $5^{\text {th }}, 2020$ ]. Available at: https: / / www.who.int/ nutrition/publications / obesity/ $\mathrm{WHO}_{-}$ TRS_894/en/.

10. Ortega Anta RM, López-Sobaler AM, Aparicio Vizuete A, González Rodríguez LG, et al. Estudio ALADINO 2015: Estudio de Vigilancia del Crecimiento, Alimentación, Actividad Física, Desarrollo Infantil y Obesidad en España 2015. Madrid: Ministerio de Sanidad, Servicios Sociales e Igualdad. Agencia Española de Consumo, Seguridad Alimentaria y Nutrición; 2016. [Accessed on: November $\left.15^{\text {th }}, 2020\right]$. Available at: https://www.aesan.gob.es/ AECOSAN/docs/documentos/nutricion/observatorio/ Estudio_ALADINO_2015.pdf.

11. Garrido-Miguel M, Cavero-Redondo I, Álvarez-Bueno C, Rodríguez-Artalejo F, et al. Prevalence and Trends of Overweight and Obesity in European Children from 1999 to 2016: A Systematic Review and Meta-analysis. JAMA Pediatr. 2019; 173(10):e192430.

12. Lamarque M, Orden A. Prevención de la obesidad infantil: aportes desde las ciencias sociales para la intervención.
Arch Argent Pediatr. 2017; 115(2):169-74.

13. LurbeE, Redon P. Nuevos elementos enla obesidad infantil. Endocrinol Diabetes Nutr. 2019; 66(3):137-9.

14. Lobstein T, Baur L, Uauy R. Obesity in children and young people: A crisis in public health. Obes Rev. 2004; 5(Suppl 1):4-104.

15. Ortega Anta RM, López-Sobaler AM, Aparicio Vizuete A, González Rodríguez LG, et al. Estudio ENALIA 20122014: Encuesta Nacional de consumo de Alimentos en población Infantil y Adolescente. Madrid: Ministerio de Sanidad, Servicios Sociales e Igualdad. Agencia Española de Consumo, Seguridad Alimentaria y Nutrición; 2017. [Accessed on: November 15 $\left.{ }^{\text {th }}, 2020\right]$. Available at: https: / / www.aesan.gob.es / AECOSAN/ docs / documentos / seguridad_alimentaria/gestion_riesgos/Informe_ ENALIA2014_FINAL.pdf.

16. Zaragoza Casterad J, Generelo E, Aznar S, Abarca-Sos A, et al. Validation of a short physical activity recall questionnaire completed by Spanish adolescents. Eur J Sport Sci. 2012; 12(3):283-91.

17. Singh AS, Vik FN, Chinapaw MJM, Uijtdewilligen L, et al. Test-retest reliability and construct validity of theENERGYchild questionnaire on energy balance-related behaviours and their potential determinants: The ENERGY-project. Int J Behav Nutr Phys Act. 2011; 8:136.

18. Beranuy Fargues M, Chamarro Lusar A, Graner Jordania C, Carbonell Sánchez X. Validación de dos escalas breves para evaluar la adicción a Internet y el abuso de móvil. Psicothema. 2009; 21(3):480-5.

19. Cronbach LJ. Coefficient alpha and the internal structure of tests. Psychometrika. 1951; 16:297-334.

20. Astray J, Del Pino V. Hábitos de salud en la población juvenil de la Comunidad de Madrid 2017. Resultados del Sistema de Vigilancia de Factores de Riesgo asociados a Enfermedades No Transmisibles en población juvenil (SIVFRENT-J). Madrid: Boletín Epidemiológico de la Comunidad de Madrid; 2018. [Accessed on: November $\left.15^{\text {th }}, 2020\right]$. Availableat:https: / / www.comunidad.madrid/ servicios/salud/factores-riesgo-enfermedad.

21. MaggeSN, Goodman E, Armstrong SC, Daniels S, et al. The metabolic syndrome in children and adolescents: Shifting the focus to cardiometabolic risk factor clustering. Pediatrics. 2017; 140(2):e20171603.

22. Royo-Bordonada MA, Armario P, Lobos Bejarano JM, Pedro-Botet J, et al. Adaptación española de las guías europeas de 2016 sobre prevención de la enfermedad cardiovascular en la práctica clínica. Rev Pediatr Aten Primaria. 2017; 19:e1-25.

23. Recasens MA, Xicola-Coromina E, Manresa JM, Ullmo PA, et al. Impact of school-based nutrition and physical activity intervention on body mass index eight years after cessation of randomized controlled trial (AVall study). Clin Nutr. 2019; 38(6):2592-8.

24. Nishida C, Uauy R, Kumanyika S, Shetty P. The Joint WHO/FAO Expert Consultation on diet, nutrition and the prevention of chronic diseases: process, product and policy implications. Public Health Nutr. 2004; 7(1A):245-50.

25. Díez-Gañán L, Galán Labaca I, León Domínguez CM, Zorrilla Torras B. Encuesta de Nutrición Infantil de la Comunidad de Madrid. Madrid: Consejería de Sanidad de la Comunidad de Madrid; 2008. [Accessed on: November 15 $\left.{ }^{\text {th }}, 2020\right]$. Available at: http://www.madrid.org/cs/ Satellite?blobcol=urldata\&blobheader $=$ application $\% 2 \mathrm{~F}$ pdf\&blobheadername1=Content-disposition\&blobhead ername $2=$ cadena\&blobheadervalue $1=$ filename $\% 3$ DEncuestaNutriciónInfantilCM-0102.pdf\&blobheadervalue2= language \%3Des\%26site \%3DPortalSalud\&blobkey $=\mathrm{id} \& \mathrm{~b}$ lobtable $=$ MungoBlobs\&blobwhere $=1220618210755 \&$ ssbi 
nary $=$ true.

26. Organización Mundial de la Salud. Recomendaciones mundiales sobre actividad física para la salud. Ginebra: OMS; 2010. [Accessed on: November $15^{\text {th }}, 2020$ ]. Available at: https://apps.who.int/iris/bitstream/ handle/10665/44441/9789243599977_spa.pdf?ua=1.

27. Madrona Marcos F, Panisello Royo J, Carbayo Herencia J, Alins J, et al. Intervención motivacional de la obesidad en Atención Primaria mediante un programa de actividad física. Nutr Hosp. 2020; 37(2):275-84.

28. Wijnhoven TMA, Van Raaij JMA, Spinelli A, Rito AI, et al. WHOEuropean Childhood Obesity Surveillance Initiative 2008: Weight, height and body mass index in 6-9-year-old children. Pediatr Obes. 2013; 8(2):79-97.
29. Cox R, Skouteris H, Dell'Aquila D, Hardy LL, et al. Television viewing behaviour among pre-schoolers: Implications for public health recommendations. J Paediatr Child Health. 2013; 49(2):E108-11.

30. Redinger RN. The prevalence and etiology of nongenetic obesity and associated disorders. South Med J. 2008; 101(4):395-9.

31. Griffiths LJ, Parsons TJ, Hill AJ. Self-esteem and quality of life in obese children and adolescents: A systematic review. Int J Pediatr Obes. 2010; 5(4):282-304.

32. Grao-Cruces A, Nuviala A, Fernández-Martínez A, PorcelGálvez AM, et al. Adherencia a la dieta mediterránea en adolescentes rurales y urbanos del sur de España, satisfacción con la vida, antropometría y actividades físicas y sedentarias. Nutr Hosp. 2013; 28(4):1129-35. 